\title{
Resilience and Spirituality as Correlates of Psychological Well- Being among Adolescents
}

\author{
Thanooja Faisal $^{1 *}$, Seena M. Mathai ${ }^{2}$
}

\section{ABSTRACT}

All human beings experience a transitional stage from puberty to adulthood that involves physical, psychological and cognitive changes (Berk,2013). Thus adolescents have to cope with several stressful life changing situations which can disrupt their psychological wellbeing. This study intends to find out if resilience and spirituality could be correlates of psychological well-being of a sample of 64 adolescents. The tools used included Brief Resilience Scale by B.W Smith et al. (2008), Scales of Psychological Well-being by C.D Ryff et al. (1999) and Spiritual Health Inventory by Beach \& Chappel (1992). The obtained results show that, there is a significant positive relationship between resilience and spirituality, and resilience and psychological well-being. It also shows the significance of gender difference in resilience. Thus, the results imply that an effort should be made at a very young age to enhance resilience, so that people will experience a better psychological wellbeing.

Keywords: Resilience, Spirituality, Psychological Wellbeing, Adolescents.

Adolescents have to cope with several life changing situations and may encounter internal pressure and tension which can disrupt their psychological well-being. Adolescence is described by Stanley Hall (1904) as 'the period of storm and stress of human life'. It is usually between 11 to 18 years of age. Adolescence is an important stage, as it pays way to adult life. Transition is always associated with problems. Problems are to be resolved properly at this stage for psychological wellbeing of the person in later life. From the perspective of positive psychology, mental health may include an individual's ability to enjoy life, and create a balance between life activities and efforts to achieve psychological resilience. According to World Health Organization (WHO) mental health includes "subjective well-being, perceived self-efficacy, autonomy, competence, intergenerational dependence, and self-actualization of one's intellectual and emotional potential, among others." It further states that the well-being of an individual is encompassed in the realization

\footnotetext{
1 BSc, Psychology, Dept. of Psychology, U.C College, Aluva, Kerala, India

${ }^{2}$ Asst. Professor, Dept. of Psychology, U.C College, Aluva, Kerala, India

*Responding Author
} 


\section{Resilience and Spirituality as Correlates of Psychological Well-Being among Adolescents}

of their abilities, coping with normal stresses of life, productive work and contribution to their community. But well-being varies for individuals and in different cultures and contexts. The scientific literature shows that females have lower psychological well-being than males. However, girls showed similar levels of psychological well-being as of boys and that it's the differential exposure and vulnerability to social roles and role characteristics that accounts for gender difference in psychological well-being (Dalila Visani et.al,2011).Another study which supports this view was conducted by Brett Roothman, Doret K. Kirsten \& Marie P. Wissing (2003).

Two individuals from the same background respond to the same adverse situation, such as a problem at work or relationship break, differently (Boardman et.al,2008). Those who face the adversity and cope with it effectively are said to be resilient. Resilience is the ability to adapt successfully to even very difficult circumstances (Berk, 2013). Resilience helps us to maintain our wellbeing in difficult circumstances. It is general rather than domain specific (Rutter, 2006) and should be considered a process than a trait to be had (Rutter .M, 2008). Resilient people make account of past and future and build resilience before they hit crisis (Nina Mguni, 2011). Two important protective factors which helps to overcome stress and contribute to resilience are good family relationships and cognitive functioning (Masten \& Coatsworth, 1998). Ahern (2006) proposed that adolescent resilience is an outcome derived from the interaction between personal attributes and characteristics, available social support, community resources and health promoting intervention. Strengthening attributes of resilience can enhance competent functioning and life outcomes (Rutter, 2006).

Significant gender difference is seen in resilience. Boardman et.al (2008) examined the possibility of resilience as a heritable trait among adults and concluded that resilience is highly heritable among men than women. Men socialize more than women and this exposure helps to gain self-esteem, mastery and other psychological resources (Pearlin \& Schooler, 1978).

Many studies have been conducted to find the link between well-being and resilience. The link between resilience and well-being was used to study the social ecological perspective by Derek Armitage et.al (2012). This link is used in rebound from serious recession, as quality of life is important and not merely material gains (Nina Mguni et.al, 2011). Both well-being and resilience are inseparable. (Nina Mguni et.al, 2011).

Research literature defines spirituality as a process of seeking personal authenticity, genuineness and wholeness; transcending ones current locus of centricity (i.e. recognizing concern beyond oneself); developing a greater connectedness to self and others through relationships and community; deriving meaning, purpose and direction in life; and openness to exploring a relationship with a higher power or powers that transcend human existence and human knowing (Love and Talbot,1999; Hill et.al 2000;Love 2001,2002; Parks 2000). It has received attention as a source of resilience for adolescents recently. Spirituality promotes healthy development in adolescents, enhances ability to cope, and leads to positive outcomes in mental health psychological well- being, and academic learning (Sangwon Kim.2011).The World Health Organisation defines wellbeing as: 'a state of mind in which an individual is 


\section{Resilience and Spirituality as Correlates of Psychological Well-Being among Adolescents}

able to realise his or her own abilities, cope with the normal stresses of life, can work productively and fruitfully, and is able to make a contribution to his or her community.'(1948). Most researches indicate that women are more religious than men. This was contradicted by a study on gender and spirituality by Rich (2012) where there was no significant difference between men and women in a spirituality test. It focused on action and community than only emotional relationships.

Many researchers have conducted studies on the role of spiritual well-being in strengthening resilience of youth. Researchers like Lindsay Smith, Ruth Webber, \& John De Frain (2013) has used mixed methods case study and concluded that spiritual wellbeing and its resilience in young people is interrelated and ecologically bound. Ahern et al. (2006) conducted study of resilience in relation to personality, cognitive styles and decision making style of management students.

Even after achieving a good career many people lack the confidence to face failures or rather setbacks. In order to overcome this and to have a better psychological well-being, an effort should be made at a very young age to enhance resilience and spirituality as the result implies. Adolescence is a time where such changes can be made and have a major impact on adult life. As resilience and spirituality are not rare qualities but are present in everyone which needs some effort and practice. In this context the researcher intends to verify if resilience and spirituality could be correlated to psychological well-being among adolescence.

\section{METHODOLOGY}

\section{Sample}

A sample of sixty four adolescence of age 15-17 was taken randomly for the study from different higher secondary schools in Aluva. The participants included 32 males and 27 females. Survey method was used to collect data for this study. First verbal concern was obtained for collecting information and said to them that the data's will be kept confidentially, use only for research purpose. The questionnaires were administered to the participants after establishing rapport with them.

\section{Tools}

Questionnaire method was used to see the relationship between the variables resilience, spirituality and wellbeing. The tools included Brief Resilience Scale developed by B.W Smith et.al (2008), Scales of Psychological Well-being by C.D Ryffet. al (1999) and Spiritual Health Inventory by Beach \& Chappel (1992). Brief Resilience Scale consists of 6 questions and Spiritual Health Inventory consists of 18 questions. Scales of Psychological Wellbeing provides scores for autonomy, environmental mastery, personal growth, positive relations with others, purpose in life and self-acceptance. It consists of 18 questions as well. Respondents rate statements on a scale of 1 to 6 , with 1 indicating strong disagreements and 6 indicating strong agreement. All the scales are found to have adequate reliability and validity. 


\section{Resilience and Spirituality as Correlates of Psychological Well-Being among Adolescents}

\section{Analysis}

SPSS version 16 was used for analyzing the data. Pearson Correlation method was used to find the correlation between resilience, spirituality and wellbeing. ' $t$ ' test was used to verify the significance of difference between different gender groups.

\section{RESULTS AND DISCUSSION}

The obtained data was analyzed using SPSS version 16 and the obtained results are discussed in the following sessions.

Table 1: The ' $t$ ' value obtained for males and females in the variable resilience, spirituality and well-being

\begin{tabular}{|c|c|c|c|c|c|}
\hline Variable & Gender & $\mathbf{N}$ & $\begin{array}{llll}\mathbf{M} & \mathbf{e} & \mathbf{a} & \mathbf{n}\end{array}$ & Std. Deviation & $c^{\prime}, \quad v$ a $l$ u e \\
\hline \multirow[t]{2}{*}{ Resilience } & Male & 32 & 19.71 & 3.14 & \multirow{2}{*}{ 2.68* } \\
\hline & Female & 27 & 17.37 & 3.57 & \\
\hline \multirow[t]{2}{*}{ Wellbeing } & Male & 32 & 92.56 & 12.41 & \multirow[t]{2}{*}{0.261} \\
\hline & Female & 27 & 91.66 & 13.92 & \\
\hline \multirow[t]{2}{*}{ Spirituality } & Male & 32 & 85.18 & 13.94 & \multirow[t]{2}{*}{0.351} \\
\hline & Female & 27 & 83.88 & 14.61 & \\
\hline
\end{tabular}

*significance at 0.05 level

From the above table it is found that there is a significant gender difference in the variable resilience at 0.05 level but the other variables do not show any significant gender difference. Males showed higher levels of resilience than females. This significant gender difference seen in resilience was also found by Jason D. Boardman et.al (2008) as he examined the possibility of resilience as a heritable trait among adults and concluded that resilience is highly heritable among men than women. Another reason for this difference is that men socialize more than women and this exposure helps to gain self-esteem, mastery and other psychological resources (Pearlin \& Schooler, 1978).

It is clear from the table that there is no significant gender difference in psychological wellbeing. Girls showed similar levels of psychological well-being as of boys and that it's the differential exposure and vulnerability to social roles and role characteristics that accounts for gender difference in psychological well-being (Dalila Visani et.al, 2011). Another study which supports this view was conducted by Brett Roothman, Doret K. Kirsten \& Marie P.Wissing (2003).

A study on gender and spirituality by Alvin Rich, II (2012) found that there is no significant difference between men and women in a spirituality test which focused on action and community than only emotional relationships.

Table-2 shows the correlation of resilience with spirituality and well-being.

\begin{tabular}{|c|c|c|c|c|}
\hline \multirow{3}{*}{\begin{tabular}{|l} 
V a ria b le \\
Resilience
\end{tabular}} & & Resilience & Spirituality & W e ll be ing \\
\hline & Pearson Correlation & & 537 & 0.677 \\
\hline & $\mathrm{N}$ & & 6 & 6 \\
\hline
\end{tabular}

(C) The International Journal of Indian Psychology, ISSN 2348-5396 (e)| ISSN: 2349-3429 (p) | 26 


\section{Resilience and Spirituality as Correlates of Psychological Well-Being among Adolescents}

Pearson Correlation shows that resilience and spirituality are found to be significantly related to well-being. This may be because resilience skills and the immediate social supports and resources are important protective factors which may help a person cope with the stress. Research has shown that people can learn and use specific resilience skills (such as optimistic thinking, relaxation strategies, choosing one's attention) and positive routines (good sleep, scheduling in fun, and so on) in order to better manage stress, bounce back quicker after a setback, be more effective in their academic and vocational pursuits, develop stronger relationships with others, be physically and mentally healthy, and be satisfied with their lives overall.

Resiliency is not only about a person's ability to positively adapt in the face of adverse or challenging circumstances, but it is also about learning the positive skills, strategies and routines that enable one to live a happy, fulfilling, and meaningful life. The link between resilience and well-being was used to study the social ecological perspective by Armitage et.al (2012) and they found that this link is used in rebound from serious recession, as quality of life is important and not merely material gains. Mguni et.al, 2011 found that wellbeing is strongly related to resilience and there is a considerable overlap in the variables that contribute to wellbeing and resilience. An individual's resilience does contribute to how satisfied he/she feels with his life and how capable he is able to cope with crisis. And both well-being and resilience are inseparable. (Nina Mguni et.al, 2011).Lindsay, Smith, Ruth Webber, \& John De Frain (2013) has used mixed methods case study and concluded that spiritual wellbeing and its resilience in young people is interrelated and ecologically bound.

Likewise spirituality is to do with deep feelings and beliefs - both religious and non-religious - and it involves many factors such as morals and principles, ethics and values, one's connection to others or relationships with them, and a sense of belonging. It has also been described as acceptance of being human and a sense of wholeness, irrespective of intellectual ability. It is believed that when a person is spiritually healthy his inner selves can be in harmony with the world around, even when he is under emotional, mental or physical stress. This greatly enhances an individual's ability to perform and contribute meaningfully in daily life which contributes to better well-being. This is supported by a Study by Florito \& Ryan (2007) where he found that spiritual goals enhance psychological well-being. Ivtzan et al (2012) found that Individuals with higher levels of spirituality (with or without religion) showed higher levels of self-actualization and meaning in life, while higher levels of personal growth initiative were only found for the group combining high levels of religiosity with spirituality. This is also supported by Litwinczuk and Groh (2007) that spirituality and purpose in life were significantly correlated. Scale set.al. (2014) also examined the correlations between spiritual development constructs and outcomes in the physical, psychosocial, civic, and academic domains of well-being and found that higher scores on the Youth Spiritual development Index are linked with successively better well-being outcomes for youth of diverse cultures and spiritual and religious beliefs. 


\section{CONCLUSION AND LIMITATIONS}

The conclusions obtained are as follows

- There is a significant gender difference in the variable resilience and Males are found to be significantly higher in the level of resilience than females.

- There is a significant relationship between resilience and spirituality with well-being.

One limitation of this is limited number of samples taken for the study was only 69. Hence the results cannot be generalized.

\section{Acknowledgments}

The author appreciates all those who participated in the study and helped to facilitate the research process.

Conflict of Interests: The author declared no conflict of interests.

\section{REFERENCES}

Ahern, N. R. (2006). Adoloescent resilience: An evolutionary concept analysis. Journal of Pediatric Nursing, Vol.21, Pp:175-185.

Alvin. R. (2012). Gender and Spirituality, A Senior Thesis submitted in partial fulfillment of the requirements for graduation in the Honors Program. Liberty University Obtained fromhttp:www.digitalcommons.liberty.edu/cgi/viewcontent.cgi?article=1293...honors (Oct. 10 2014)

Bacon, N., \& Mguni, N. (2010), Taking the temperature of local communities, The Young Foundation.

Berk, L. E. (2013).Child Development.9th edition. Pearson education Inc.

Boardman, J.D., Blalock, C.L. Button, T.M.M.(2009). Sex differences in the Heritability of Resilience. Twin research and Human Genetics: Journal of the International Society for Twin Studies, Vol.11. Iss.1, Pp.12-27.

Chappel, J.N. (1995). The Spiritual Health Inventory. University of Nevada-Reno

Florito, B., \&Ryan, K. (2007). Spirituality and Psychological well-being a mediator moderator study, Review of religious research, Vol. 48, Iss.4 , Pp.361-68.

Hill, P.C., Pargament, K.L., Hood, R.W., McCullough, M. E., Swyers, E.L. (2001). Conceptualizing Religion and Spirituality: Points of commodity, Points of departure. Journal for the Theory of Social Behaviour, Vol.30, pp51-77.

Ivtzan, I., Chan, C.P.L., Gardner, H.E., \& Prashar, K. ( 2012). .Linking Religion and Spirituality with Psychological Well-being: Examining Self-actualisation, Meaning in Life, and Personal Growth Initiative, Journal of Religious health, Vol.48, Pp. 0022-4197

Kim, S. \& Esquivel, G. B. (2011). Adolescent spirituality and resilience: Theory, research, and educational practices. Psychology in . Schools, Vol.48, Pp. 755-765.

Litwinczuk, K. M., \& Groh, C. H. (2007). The relationship between spirituality, purpose in life, and well-being in HIV-positive persons. Journal of Association of Nurses AIDS Care, Vol.18. Iss.3, Pp. 13-22. 
Love, P.G. (2002).Comparing Spiritual Development and Cognitive Development. Journal of College Student Development, Vol. 43, Pp357-373.

Love, P.G. ,\& Talbot, D.(1999). Defining Spiritual Development: A missing consideration for student affairs. National Association of Student Personnel Administrators Journal, Vol. 37, Pp:361-375.

Love, P.G.(2001). Spirituality and Student Development: Theoretical connections, M.A. Jablonski edition. The implications of student spirituality for student affairs practice: New directions for student services. San Fransisco: Jossy-Bass; pp 7-16.

Masten, A. S., \& Coatsworth, J.D.(1998). The development of competence in favorable and unfavorable environments: Lessons from research on successful children. American Psychologist, Vol. 53, Pp:205-220.

Mguni, Nina, and Bacon, N. (2010). Taking the Temperature of Local Communities, the Wellbeing and Resilience Measure (Warm). London: The Young Foundation Local Wellbeing Project.

Perks, S.D.(2000). Big Questions, Worthy Dreams: Mentoring Young Adults In Their Search for Meaning Purpose and Faith. San Fransisco: Jossy-Bass.

Richard, E. A. (1974). "Does Economic Growth Improve the Human Lot?" in Paul A. David and Melvin W. Reder, eds., Nations and Households in Economic Growth: Essays in Honor of Moses Abramovitz, New York: Academic Press, Inc

Roothman, B.,Kirsten, D.,Wissing, M. (2003). Gender Differences in aspects of psychological well-being.South African Journal of Psychology. Vol.33, Iss.4, Pp.212-218.

Rutter, M. (2003). Genetic influences on risk and protection: Implications for understanding resilience. In: Luthar SS, editon. Resilience and vulnerability: Adaptation in the context of childhood adversities. Cambridge University Press.

Rutter, M. (2006). Implications of resilience concepts for scientific understanding. Annals of the New York Academy of Science; 1094:Pp. 1-12.

Ryff, C.D., \& Singer, B. (1998).The contours of positive human health. Psychological Inquiry, Vol.9, Pp: 1-28.

Scales, P. C., Syyertsen, A. K., Benson, P. L., Roehlkepartain, E. C., \& Sesma, A. (2014). Relation of Spiritual Development to Youth Health and Well-Being: Evidence from a Global Study, Handbook of child well-being, New York, Springer. Pp. 1101-1135.

Smith, B. W., Dalen, J., Wiggins, K., Tooley, E., Christopher, P., \& Bernard, J. (2008). The brief resilience scale: assessing the ability to bounce back. International Journal of Behavioral Medicine, Vol.15, Pp.194-200.

Stanley, H. J. (1904). Adolescence, Its Psychology and Its Relations to Physiology, Anthropology, Sociolog.Sex, Crime, Religion and Education. Vol.2.

Visani, D., Albieri, E., Offidani, I., Ottolini, F. (2011). Gender Differences in Psychological Well-being and Distress During Adolescence: The Human Pursuit of wellbeing, Springer Netherlands Publisher, Pp. 65-70.

How to cite this article: Faisal T, Mathai S M (2017), Resilience and Spirituality as Correlates of Psychological Well-Being among Adolescents, International Journal of Indian Psychology, Volume 4, (3), DIP:18.01.143/20170403, DOI:10.25215/0403.143

(C) The International Journal of Indian Psychology, ISSN 2348-5396 (e)| ISSN: 2349-3429 (p) | 29 